\title{
Evaluasi Media Pembelajaran Interaktif Pengenalan Tata Surya dengan Teknologi Augmented
}

\section{Reality dan Virtual Reality}

\author{
Fendi Aji Purnomo¹, Sastri Jendra Ayunigrat², Yoana Lukitasari ${ }^{3}$, Arrofvianti Nurwhinda Kusuma ${ }^{4}$ \\ fendi_aji@mipa.uns.ac.id
}

\begin{abstract}
The solar system is something that is learned but cannot be seen directly by students. Planet props available in laboratory are also very limited and presented in conventional models so that students are less interested in learning further with the existing planetary models. This study aims to evaluate the results of making astronomy learning media applications with Augmented Reality and Virtual Reality technology. This application is designed and developed using the MDLC method, namely concept, design, material collecting, assembly, testing and distribution stages. This interactive media is packaged using Augmented Reality and Virtual Reality technology which are presented in interactive catalog. This study have created the Android-based learning media of the Milky Way Galaxy Planet System. The material is presented in form of discussion about the Solar System that is taught in Middle School. This application can be run optimally with Quadcore $1.5 \mathrm{Ghz}$ device specifications which has 3 GB RAM and gyro sensor. The assessment results from junior high school students on Design and Information Aspects get a Very Good and Very Good grades of $100 \%$, then Navigation Aspects scores of $99.9 \%$.
\end{abstract}

Keywords: $\quad$ Interactive media, solar system, AR and VR

Abstrak: $\quad$ Tata surya merupakan suatu hal yang dipelajari namun tidak dapat dilihat secara langsung oleh siswa. Alat peraga planet yang ada pada laboratorium juga sangat terbatas jumlahnya dan berbentuk model konvensional sehingga siswa kurang tertarik untuk memperlajari lebih lanjut dengan model planet yang ada. Penelitian ini bertujuan mengevaluasi hasil pembuatan aplikasi media pembelajaran astronomi dengan teknologi Augmented Reality dan Virtual Reality. Aplikasi ini dirancang dan dikembangkan menggunakan metode MDLC yaitu tahap konsep, desain, material collecting, assembly, testing dan distribution. Media interaktif ini dikemas dengan menggunakan teknologi Augmented Reality dan Virtual Reality yang disajikan pada katalog interaktif. Hasil penelitian ini telah tercipta media pembelajaran Model Planet Tata Surya Galaksi Bima Sakti berbasis Android. Materi yang disajikan berupa pembahasan tentang Tata Surya yang diajarkan di Sekolah Menengah Pertama. Aplikasi ini dapat dijalankan secara optimal dengan spesifikasi perangkat Quadcore $1.5 \mathrm{Ghz}$ serta memiliki RAM $3 \mathrm{~GB}$ dan memiliki sensor gyro. Hasil penilaian dari siswa SMP pada Aspek Desain dan Aspek Informasi mendapatkan nilai Sangat Baik dan Sangat Baik Sekali sebesar 100\%, serta Aspek Navigasi sebesar 99.9\%.

Kata Kunci: $\quad$ Media interaktif, tata surya, AR dan VR

Submitted: Oktober $2019 \quad$ Reviewed: Oktober $2019 \quad$ Accepted: Februari $2020 \quad$ Published: Maret 2020

\footnotetext{
1 Teknik Informatika, Universitas Sebelas Maret

2 Teknik Informatika, Universitas Sebelas Maret

3 Teknik Informatika, Universitas Sebelas Maret

4 SMP Al Azhar Syifa Budi
} 


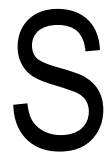

iswa sekolah menengah pertama mempelajari system tata surya galaksi bima sakti pada kelas Sembilan. Materi tatasurya (planet) sangat penting untuk dipelajari dan dimengerti karena termasuk kedalam kisi-kisi soal ujian berstandar nasional mata pelajaran IPA dari tahun ketahun hingga yang terbaru adalah tahun 2019. Dalam pembelajaran di sekolah system tata surya (Prayudha, Agung, Wiranatha, \& Raharja, 2017; Sugianto, 2015) dipelajari dengan materi dalam gambar 2 dimensi(Mallem, 2010; F.A. Purnomo, Santosa, Hartanto, Pratisto, \& Purbayu, 2018). Tidak banyak alat peraga di laboratorium ilmu pengetahuan alam dalam memodelkan tata surya tersebut. Namun dalam prakteknya siswa kurang tertarik dengan model pembelajaran dengan alat peraga yang terkesan konvensional. Akses untuk melihat alat peraga tersebut juga terbatas waktu dan jumlah. Alat peraga tersebut bisa diakses saat mata pelajaran dan harus dengan pengawasan guru pengajar. Siswa juga tidak dapat sepuasnya mengerti dalam mengamati alat peraga tersebut karena jumlahnya terbatas.

Augmented Reality (Azuma \& Azuma, 1997)merupakan teknologi yang mampu menggabungkan objek maya dua dimesi ataupun tiga dimensi ke dalam sebuah lingkungan nyata dan dihadirkan dengan (real time). Teknologi ini merupakan salah satu teknologi yang menarik sekaligus mudah dipahami oleh siswa dalam proses belajarnya (Fendi Aji Purnomo, Santoso, \& Hartanto, 2017; C. Wang, 2012) (Z. B. Wang, Shen, Ong, \& Nee, 2009). Objek yang akan ditampilkan menggunkan alat bantu media kartu AR. Hal ini merupakan interaksi pengguna dengan dunia nyata kepada objek yang ditampilkan. Pengemasan media ajar dengan teknologi AR telah dibuktikan oleh (Fleck, Simon, \& Bastien, 2014) (Chang et al., 2014), yaitu aplikasi AR mampu meningkatkan keterlibatan dan kenikmatan belajar siswa. Sedangkan virtual reality merupakan teknologi yang mampu menghadirkan objek nyata kedalam objek fiksi 3 Dimensi (Feng, González, Amor, Lovreglio, \& Cabrera-guerrero, 2018; Tussyadiah, Wang, Jung, \& Claudia, 2018)secara langsung (realtime) seolah kita sedang melihat suatu objek secara nyata di depan mata. Teknologi ini menggunakan media berupa kacamata VR sehingga mampu melihat dalam bentuk 3 Dimensi. Penggunaan virtual reality dalam transfer materi pembelajaran mampu menaikkan pemahaman siswa, hal ini telah dibuktikan oleh (Ahmad, Wan, \& Ahmad, 2017) (Gelisli \& Yazici, 2015; Geroimenko, 2012; Nassar \& Meawad, 2010; Z. B. Wang et al., 2009)

Penelitian yang dilakukan bertujuan mengevaluasi media pembelajaran interaktif yang mengutamakan pengalaman belajar siswa serta keleluasaan siswa dalam memilih informasi untuk belajar. Media belajar sebelumnya telah dikembangkan oleh (Prayudha et al., 2017) (K.Wahyudi, 2014). Pada karya tulis ini terdapat kelebihan diantaranya menyajikan tata surya dalam bentuk virtual reality, namun secara garis besar terdapat kekurangan diantaranya tidak adanya menu latihan soal.

Untuk karya tulis kedua ditulis oleh (Sugianto, 2015), karya tulis ini berjudul Aplikasi Edukasi Tata Surya Menggunakan Augmented Reality Berbasis Mobile. Aplikasi ini memiliki kelebihan diantaranya adalah berbentuk mobile, karena dapat memudahkan dalam proses implementasi oleh guru dan siswa. Namun terdapat kekurangan diataranya kualitas gambar/model 3D belum baik. Serta proses loading aplikasi yang sangat lama.

\section{METODE PENELITIAN}

Penelitian yang membuat aplikasi multimedia interaktif menggunakan teknologi AR (Ajanki et al., 2011) (C. Wang, 2012) (Lin, Wang, \& Liu, 2008) dan VR (Ahmad et al., 2017) (Silva, Oliveira, \& Giraldi, n.d.) (Prayudha et al., 2017) dalam mengenalkan materi tata surya. Tahap pembuatan aplikasi dilakukan dengan menggunakan metode Multimedia Development Life Cycle (MDLC) yang terdiri dari tahap konsep, desain, material collecting, assembly, testing dan distribution (Luther, 1994).

Tahap konsep, pembelajaran tata surya bersumber dari silabus kurikulum 2013 untuk SMP. Materi tersebut akan dikemas menggunakan teknologi AR dalam mejelaskan tata surya, sehingga memerlukan 
marker cetak untuk memunculkan objek virtual baik 2D maupun 3D. Sedangkan simulasi dan animasi planet dan matahari dikemas dengan teknologi VR, memungkinkan siswa untuk explorasi materi secara mandiri dalam mode lingkungan games 1 st person. Tahap desain, dilakukan pembuatan user interface dalam model storyboard untuk setiap tampilan menu. Tahap material collecting, diperlukan gambar illustrasi, audio, icon dan model objek 2D maupun 3D yang mendukung pembelajaran tata surya. Kebutuhan software yang diperlukan yaitu Blender, Corel, Vuforia dan Unity. Tahap Assembly merupakan pembuatan seluruh objek 3D untuk materi tata surya berdasar storyboard yang telah ditentukan. Tahap testing dilakukan dengan cara black box dengan memastikan bahwa seluruh navigasi telah berfungsi dengan baik. Tahap testing juga dilakukan pengujian aplikasi pada perangkat smartpone yang memiliki sensor gyroskop dengan memory RAM berlainan, bertujuan untuk mengetahui kriteria minimal aplikasi dapat berjalan. Tahap terakhir yaitu distribution dilakukan dengan mempublish script pemrograman menjadi aplikasi siap install dalam bentuk APK dan kemudian diujikan kepada responden melalui form kuisioner dalam pengalaman mencoba aplikasi pembelajaran tata surya meliputi aspek penyampaian informasi, aspek kebaikan desain visual dan aspek kejelasan audio. Apabila dalam tahap ini terdapat kekurang kemudian segera dibenahi dan dilakukan publikasi ulang. Responden yang terpilih dalam pengujian ini adalah anak kelas SMP.

\section{HASIL DAN PEMBAHASAN}

Tahap pembuatan aplikasi dilakukan dengan menggunakan metode Multimedia Development Life Cycle (MDLC) ditunjukkan pada Gambar 3, terdiri dari tahap pertama yaitu konsep. Membuat konsep yaitu dengan validasi yang telah dilakukan pada penggunaan teknologi Augmented Reality (Gelisli \& Yazici, 2015) dan Virtual Reality (Ahmad et al., 2017). Dalam penelitian ini menggunakan teknologi yang sama untuk pembelajaran planet dalam tata surya sebagai media pembelajaran siswa sekolah menengah pertama. Rancangan produk dalam bentuk modelling, story board, animation objek sehingga tercipta produk Aplikasi Augmented Reality dan Virtual Reality Planet menggunakan software Belnder $2.79 \mathrm{~b}$.

Design dilakukan dengan membuat storyboard sebagai gambaran alur perancangan desain tampilan menggunakan deskripsi dari masing - masing objek yang dibuat. Storyboard digunakan sebagai acuan pembuatan aplikasi ini. Desain navigasi menu terdiri dari menu Edukasi, Laboratorium dan Latihan Soal.

Material Collecting, di dalam pembuatan aplikasi ini diperlukannya gambar, audio, icon, dan objek 3D meliputi ilustrasi planet. Bahan yang dibutuhkan akan dibuat menggunakan software CorelDraw, Adobe Photoshop, Blender, dan Unity. Gambar 1 merupakan salah satu contoh material berupa teksture untuk membuat planet Venus.

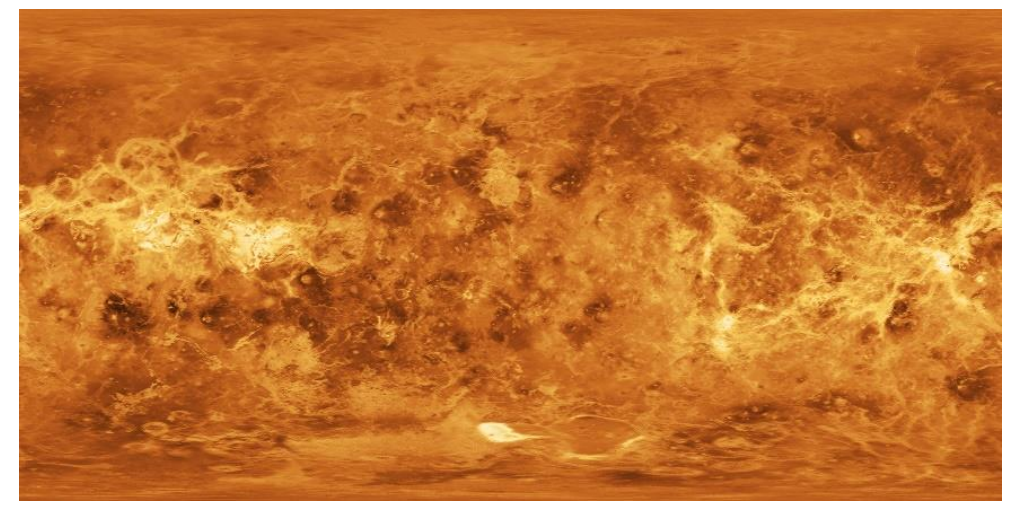

Gambar 1. Tekstur untuk planet Venus 
Assembly, pembuatan seluruh objek 3D berdasarkan storyboard atau perancangan yang telah dibuat seperti Gambar 2 untuk contoh planet Venus

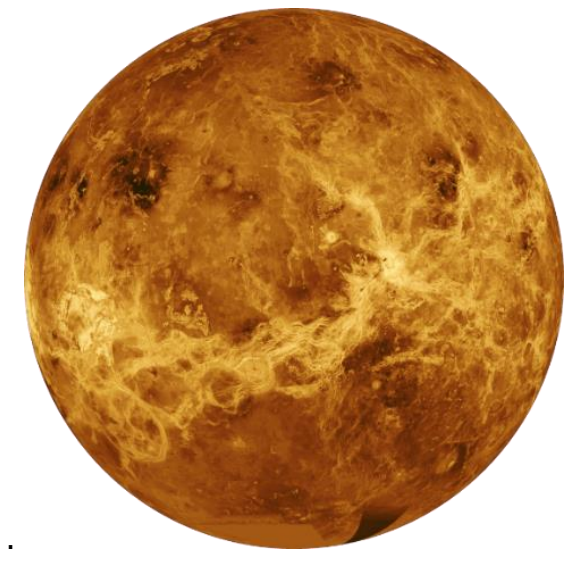

Gambar 2. Hasil jadi planet Venus

Testing dilakukan dengan pengujian aplikasi tujuannya untuk menguji dan memastikan bahwa aplikasi telah berjalan dengan baik. Testing ini nanti akan dilakukan oleh siswa dan guru dari SMP Negeri 1 Wonoasri.

Distribution, tahap ini dilakukan untuk menyebarluaskan Augmented Reality dan Virtual Reality Gaya dan Usaha Sebagai Media Pembelajaran Siswa Sekolah Menengah Pertama melalui playstore kepada masyarakat luas.

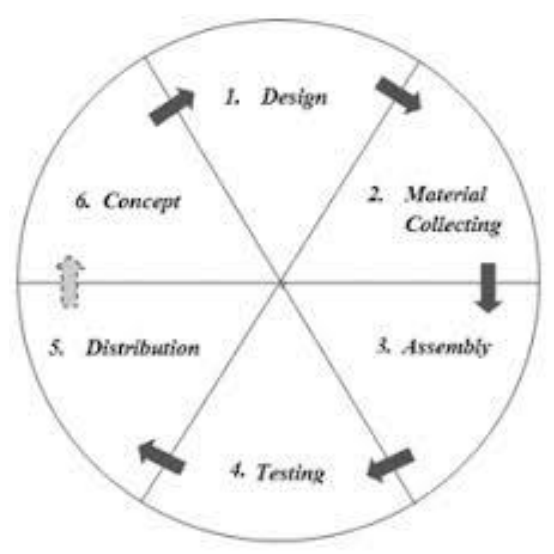

Gambar 3. Grafik MDLC

Pada proses produksi ini menggunakan asset yang digunakan dan dibutuhkan dalam aplikasi Augmented Reality dan Virtual Reality Model Planet Tata Surya Galaxy Bima Sakti Sebagai Media Pembelajaran. Pada tahapan produksi ini ada beberapa aplikasi yang dipergunakan, diantaranya adalah : Blender : Untuk pembuatan Asset Model 3D, CorelDraw : Pembuatan Asset 2D, Adobe Audition : Pembuatan Asset Audio. Serta Unity 3D yang berfungsi untuk menyatukan asset serta implementasi proses pembuatan aplikasi.

Dalam tahap produksi ini dilakukan dengan bertahap yang mana dimulai dari pembuatan objek 3D dengan menggunakan Blender, lalu pembuatan audio sound berupa dubbing dengan menggunakan aplikasi Adobe Audition, lalu pembuatan objek 2D serta pembuatan user interface dengan menggunakan aplikasi CorelDraw. Lalu semua objek tersebut digabungkan dan dikumpulkan dan diimpor kedalam projek folder yang terdapat pada aplikasi Unity 3D Game Engine dan dijadikan dalam bentuk asset. 
Hasil pembuatan aplikasi AR dan VR astronomi untuk tampilan menu utama disajikan pada Gambar 4. Aplikasi AR dapat berjalan pada HP android menggunakan bantuan marker seperti ditunjukkan pada Gambar 5. Sedangkan aplikasi VR dapat berjalan menggunakan bantuan VR headset dan perangkat android yang mendukung sensor gyroskop, tampilan mode VR ditunjukkan pada Gambar 6.

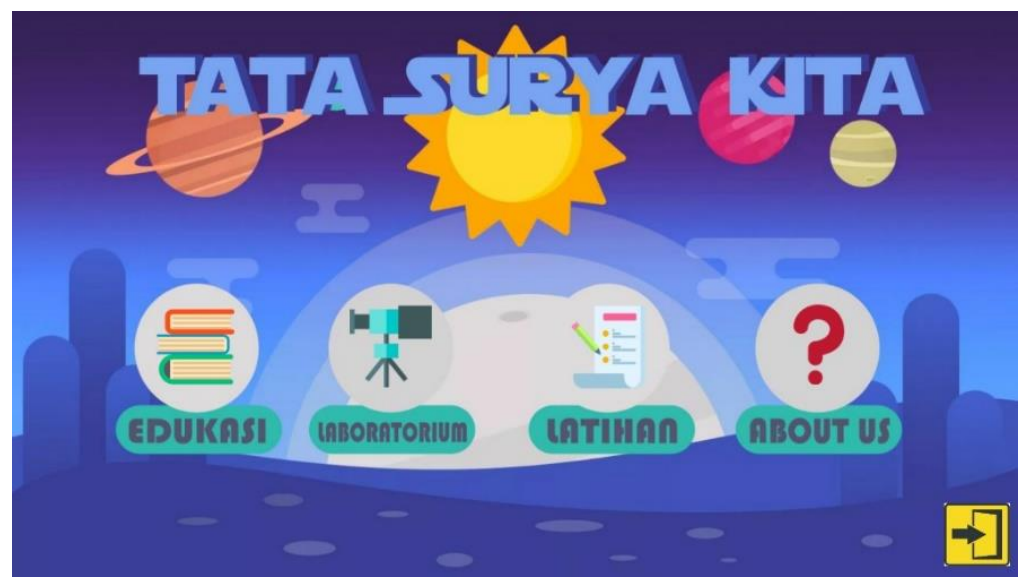

Gambar 4. Tampilan menu utama aplikasi pembelajaran AR dan VR Astronomi

Berdasarkan Gambar 4, ketika pengguna menekan tombol menu edukasi, dan marker di hadapkan pada kamera maka akan muncul tampilan objek virtual planet dalam model 3D sesuai nama planet pada marker tersebut, dalam hal ini menggunakan teknologi augmented reality. Selain muncul objek virtual 3D planet juga muncul infoormasi mengenai planet tersebut dan posisi planet tersebut dalam galaksi. Tampilan menu edukasi ketika marker dapat dikenali seperti ditunjukkan pada Gambar 5.

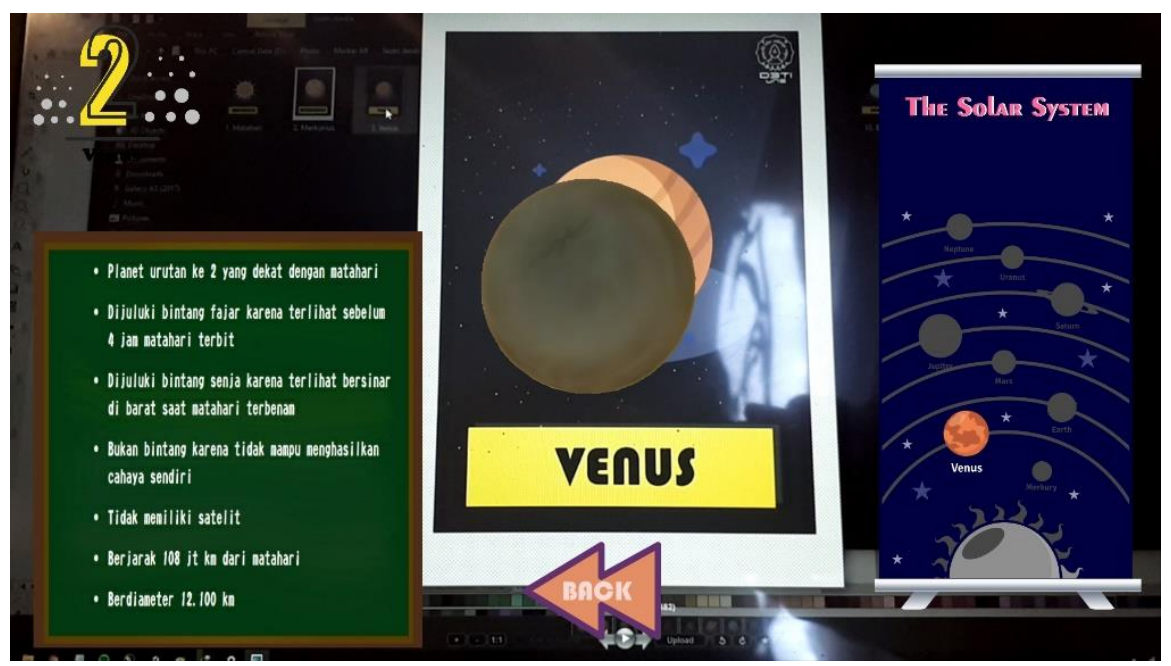

Gambar 5.Tampilan Menu Edukasi yang memanfaatkan marker untuk belajar dan dibangun dengan teknologi augmented reality

Ketika pengguna menekan tombol menu Latihan atau uji kompetensi, maka akan muncul tampilan menu latihan. Dalam menu latihan informasi virtual dapat dimunculkan dengan bantuan marker 
tertentu yang sudah didaftarkan. Untuk menjawab soal yang ada di menu latihan ini pengguna cukup menutup salah satu marker yang sudah disiapkan untuk pilihan $A, B, C$ atau $D$. Tampilan menu latihan seperti ditunjukkan pada Gambar 6.

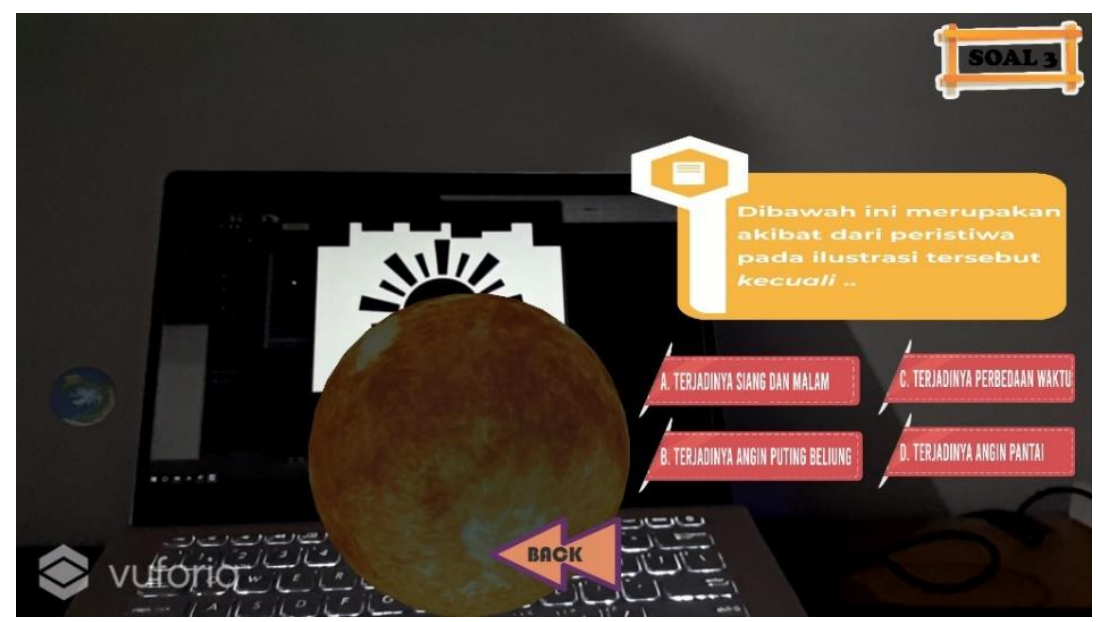

Gambar 6. Tampilan Menu Latihan dibuat dengan teknologi Augmented Reality

Ketika pengguna menekan tombol menu Laboratorium, maka tampilan berupa Virtual Reality yaitu tampilan layar yang terbagi menjadi dua dan sama persis (stereoskopis). Dalam tampilan VR ini pengguna dapat secara leluasa bereksplorasi untuk memperoleh informasi nama-nama planet yang berputar mengelilingi matahari. Pengguna dapat berinteraksi untuk melihat informasi tiap planet dengan bantuan headset kursor yang diarahkan beberapa detik pada salah satu planet. Tampilan VR dalam menu laboratorium ditunjukkan pada Gambar 7.

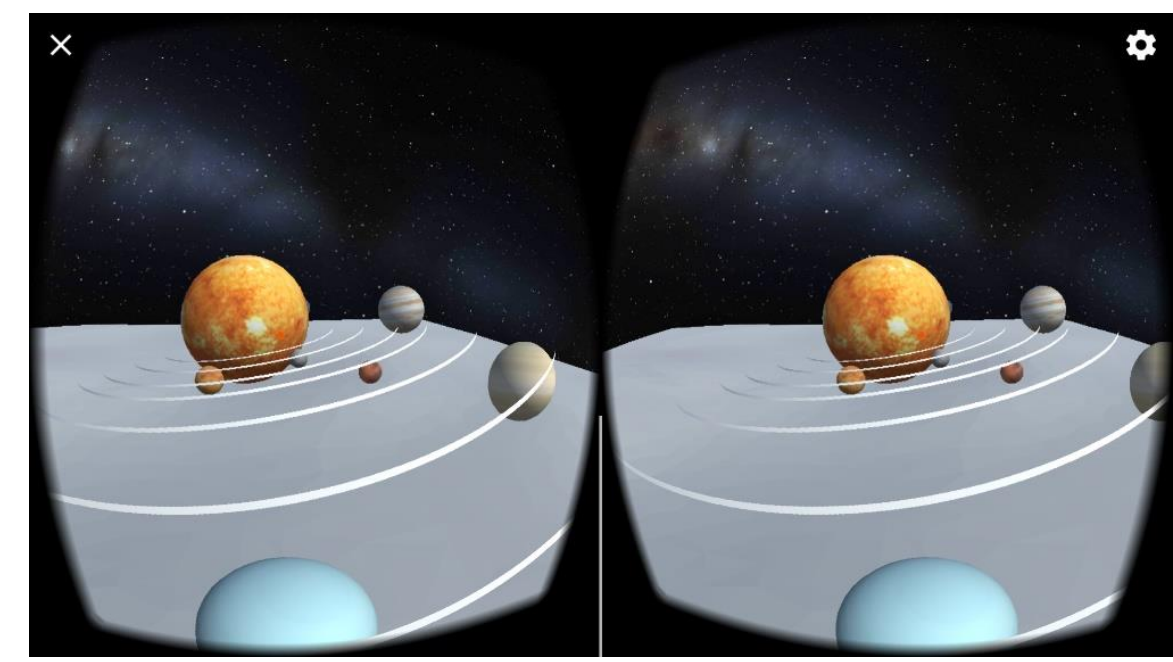

Gambar 7. Tampilan Menu Laboratorium dengan teknologi Virtual Reality Pengujian Aplikasi

Adapun hasil pengujian terkait fungsionalitas aplikasi ada pada Tabel 1.

Tabel 1. Pengujian Fungsionalitas Perangkat

\begin{tabular}{llll}
\hline No & Jenis Perangkat & Tes & Keterangan \\
\hline
\end{tabular}




\begin{tabular}{|c|c|c|c|}
\hline \multirow{5}{*}{1} & \multirow{5}{*}{$\begin{array}{l}\text { Xiaomi Redmi Note } 2 \\
\text { (Mediatek MT5795 Helio } \\
\text { X10 Octacore 2Ghz } \\
\text { PowerVR G6200 } \\
\text { Accelerometer, Gyro, } \\
\text { Proximity, Compass } \\
\text { GB) }\end{array}$} & Penginstalan & $\begin{array}{l}\text { Proses penginstalan membutuhkan } \\
\text { waktu } 36 \text { detik }\end{array}$ \\
\hline & & Loading Aplikasi & $\begin{array}{l}\text { Proses Loading masuk membutuhkan } \\
\text { waktu } 20 \text { detik }\end{array}$ \\
\hline & & Tombol & $\begin{array}{l}\text { Proses respon menekan tombol play } 3 \\
-5 \text { detik. }\end{array}$ \\
\hline & & Objek 3D & Seluruh objek 3D dapat ditampilkan \\
\hline & & Audio & $\begin{array}{l}\text { Seluruh audio dapat didengan dengan } \\
\text { baik }\end{array}$ \\
\hline \multirow{5}{*}{2} & \multirow{5}{*}{$\begin{array}{l}\text { Samsung Galaxy A5 } 2017 \\
\text { (Exynos } 7880 \text { Octacore } 1.9 \\
\text { Ghz, GPU Mali T-830 MP3, } \\
\text { Sensor Accelerometer, } \\
\text { Gyro, Proximity, Compass, } \\
\text { RAM } 3 \text { GB) }\end{array}$} & Penginstalan & $\begin{array}{l}\text { Proses penginstalan membutuhkan } \\
\text { waktu } 20 \text { detik }\end{array}$ \\
\hline & & Loading Aplikasi & $\begin{array}{l}\text { Proses Loading masuk ke aplikasi } \\
\text { membutuhkan waktu } 12 \text { detik }\end{array}$ \\
\hline & & Tombol & $\begin{array}{l}\text { Proses respon ketika menekan tombol } \\
\text { play membutuhkan } 1-2 \text { detik. }\end{array}$ \\
\hline & & Objek 3D & Seluruh objek 3D dapat ditampilkan \\
\hline & & Audio & $\begin{array}{l}\text { Seluruh audio dapat didengan dengan } \\
\text { baik }\end{array}$ \\
\hline \multirow{5}{*}{3} & \multirow{5}{*}{$\begin{array}{l}\text { Xiaomi Redmi Note } 5 \\
\text { (Prosessor Qualcomm } \\
\text { SDM636 Snapdragon } 636 \\
\text { Octa-core } 1.8 \text { GHz Kryo } \\
\text { 260, GPU Adreno 509, } \\
\text { Sensor Accelerometer, } \\
\text { Gyro, Proximity, Compass } \\
\quad \text { RAM } 4 \text { GB) }\end{array}$} & Penginstalan & $\begin{array}{l}\text { Proses penginstalan membutuhkan } \\
\text { waktu } 19 \text { detik }\end{array}$ \\
\hline & & Loading Aplikasi & $\begin{array}{l}\text { Proses Loading masuk ke aplikasi } \\
\text { membutuhkan waktu } 16 \text { detik }\end{array}$ \\
\hline & & Tombol & $\begin{array}{l}\text { Proses respon ketika menekan tombol } \\
\text { play membutuhkan 2-4 detik. }\end{array}$ \\
\hline & & Objek 3D & Seluruh objek 3D dapat ditampilkan \\
\hline & & Audio & $\begin{array}{l}\text { Seluruh audio dapat didengan dengan } \\
\text { baik }\end{array}$ \\
\hline
\end{tabular}

Pengujian Kemampuan Baca Marker Augmented Reality terhadap kompatibilitas perangkat ditunjukkan pada Tabel 2.

Tabel 2. Tabel Pengujian Baca Marker Perangkat Xiaomi Redmi Note 2

\begin{tabular}{|c|c|c|c|c|}
\hline No & $\begin{array}{c}\text { Kondisi Cahaya } \\
\text { (Lux) }\end{array}$ & $\begin{array}{c}\text { Sudut Baca } \\
\text { Marker }\end{array}$ & $\begin{array}{c}\text { Jarak Baca } \\
\text { Marker }\end{array}$ & Keterangan \\
\hline 1 & \multirow{3}{*}{$\begin{array}{c}20 \text { Lux } \\
\text { (kondisi malam } \\
\text { hari dengan } \\
\text { pencahayaan } \\
\text { ruangan) }\end{array}$} & 90 Derajat & $80 \mathrm{CM}$ & $\begin{array}{l}\text { - percobaan dilakukan } 2 x \\
\text { - pengenalan objek selama } 3 \\
\text { detik }\end{array}$ \\
\hline 2 & & 75 Derajat & $70 \mathrm{CM}$ & $\begin{array}{l}\text { - marker terdeteksi pada } 2 x \\
\text { percobaan } \\
\text { - pengenalan objek selama } 3 \\
\text { detik }\end{array}$ \\
\hline 3 & & 60 Derajat & $60 \mathrm{CM}$ & $\begin{array}{l}\text { - marker terdeteksi pada } 2 x \\
\text { percobaan } \\
\text { - pengenalan objek selama } 3 \\
\text { detik }\end{array}$ \\
\hline
\end{tabular}




\begin{tabular}{|c|c|c|c|c|}
\hline 4 & & 45 Derajat & $50 \mathrm{CM}$ & $\begin{array}{l}\text { - marker terdeteksi pada } 4 x \\
\text { percobaan } \\
\text { - pengenalan objek selama } 5 \\
\text { detik }\end{array}$ \\
\hline 5 & & 30 Derajat & $40 \mathrm{CM}$ & $\begin{array}{l}\text { - marker terdeteksi pada } 4 x \\
\text { percobaan } \\
\text { - pengenalan objek selama } 5 \\
\text { detik }\end{array}$ \\
\hline 6 & & 15 Derajat & $30 \mathrm{CM}$ & - marker tidak dapat terdeteksi \\
\hline 7 & & 0 Derajat & $20 \mathrm{CM}$ & - marker tidak dapat terdeteksi \\
\hline 8 & & 90 Derajat & $80 \mathrm{CM}$ & $\begin{array}{l}\text { - marker terdeteksi pada 1x } \\
\text { percobaan } \\
\text { - pengenalan objek selama } 2 \\
\text { detik }\end{array}$ \\
\hline 9 & & 75 Derajat & $70 \mathrm{CM}$ & $\begin{array}{l}\text { - marker terdeteksi pada 1x } \\
\text { percobaan } \\
\text { - pengenalan objek selama } 2 \\
\text { detik }\end{array}$ \\
\hline 10 & $\begin{array}{c}150 \text { Lux } \\
\text { (kondisi siang hari }\end{array}$ & 60 Derajat & $60 \mathrm{CM}$ & $\begin{array}{l}\text { - marker terdeteksi pada } 1 x \\
\text { percobaan } \\
\text { - pengenalan objek selama } 2 \\
\text { detik }\end{array}$ \\
\hline 11 & $\begin{array}{c}\text { dengan } \\
\text { pencahayaan } \\
\text { dalam ruangan) }\end{array}$ & 45 Derajat & $50 \mathrm{CM}$ & $\begin{array}{l}\text { - marker terdeteksi pada 1x } \\
\text { percobaan } \\
\text { - pengenalan objek selama } 2 \\
\text { detik }\end{array}$ \\
\hline 12 & & 30 Derajat & $40 \mathrm{CM}$ & $\begin{array}{l}\text { - marker terdeteksi pada 1x } \\
\text { percobaan } \\
\text { - pengenalan objek selama } 2 \\
\text { detik }\end{array}$ \\
\hline 13 & & 15 Derajat & $30 \mathrm{CM}$ & $\begin{array}{l}\text { - marker terdeteksi pada 3x } \\
\text { percobaan } \\
\text { - pengenalan objek selama } 3 \\
\text { detik }\end{array}$ \\
\hline 14 & & 0 Derajat & $20 \mathrm{CM}$ & - marker tidak dapat terdeteksi \\
\hline 15 & & 90 Derajat & $80 \mathrm{CM}$ & $\begin{array}{l}\text { - marker terdeteksi pada } 1 x \\
\text { percobaan } \\
\text { - pengenalan objek selama } 1 \\
\text { detik }\end{array}$ \\
\hline 16 & $\begin{array}{c}346 \text { Lux } \\
\text { (kondisi siang hari } \\
\text { dengan } \\
\text { pencahayaan }\end{array}$ & 75 Derajat & $70 \mathrm{CM}$ & $\begin{array}{l}\text { - marker terdeteksi pada 1x } \\
\text { percobaan } \\
\text { - pengenalan objek selama } 1 \\
\text { detik }\end{array}$ \\
\hline 17 & $\begin{array}{l}\text { sinar matahari } \\
\text { luar ruangan) }\end{array}$ & 60 Derajat & $60 \mathrm{CM}$ & $\begin{array}{l}\text { - marker terdeteksi pada 1x } \\
\text { percobaan } \\
\text { - pengenalan objek selama } 1 \\
\text { detik }\end{array}$ \\
\hline 18 & & 45 Derajat & $50 \mathrm{CM}$ & $\begin{array}{l}\text { - marker terdeteksi pada 1x } \\
\text { percobaan }\end{array}$ \\
\hline
\end{tabular}




\begin{tabular}{|c|c|c|c|}
\hline 19 & 30 Derajat & $40 \mathrm{CM}$ & $\begin{array}{l}\text { - marker terdeteksi pada } 1 x \\
\text { percobaan } \\
\text { - pengenalan objek selama } 1 \\
\text { detik }\end{array}$ \\
\hline 20 & 15 Derajat & $30 \mathrm{CM}$ & $\begin{array}{l}\text { - marker terdeteksi pada } 2 x \\
\text { percobaan } \\
\text { - pengenalan objek selama } 2 \\
\text { detik }\end{array}$ \\
\hline 21 & 0 Derajat & $20 \mathrm{CM}$ & - marker tidak dapat terdeteksi \\
\hline
\end{tabular}

Tabel 3. Tabel Pengujian Baca Marker Perangkat Galaxy A5

\begin{tabular}{|c|c|c|c|c|}
\hline No & $\begin{array}{l}\text { Kondisi Cahaya } \\
\text { (Lux) }\end{array}$ & $\begin{array}{l}\text { Sudut Baca } \\
\text { Marker }\end{array}$ & $\begin{array}{c}\text { Jarak Baca } \\
\text { Marker }\end{array}$ & Keterangan \\
\hline 1 & \multirow{7}{*}{$\begin{array}{l}2 \text { Lux } \\
\text { (kondisi malam } \\
\text { hari dengan } \\
\text { pencahayaan } \\
\text { ruangan) }\end{array}$} & 90 Derajat & $80 \mathrm{CM}$ & $\begin{array}{l}\text { - percobaan dilakukan } 2 x \\
\text { - pengenalan objek selama } 3 \\
\text { detik }\end{array}$ \\
\hline 2 & & 75 Derajat & $70 \mathrm{CM}$ & $\begin{array}{l}\text { - marker terdeteksi pada } 2 x \\
\text { percobaan } \\
\text { - pengenalan objek selama } 3 \\
\text { detik }\end{array}$ \\
\hline 3 & & 60 Derajat & $60 \mathrm{CM}$ & $\begin{array}{l}\text { - marker terdeteksi pada } 2 x \\
\text { percobaan } \\
\text { - pengenalan objek selama } 3 \\
\text { detik }\end{array}$ \\
\hline 4 & & 45 Derajat & $50 \mathrm{CM}$ & $\begin{array}{l}\text { - marker terdeteksi pada } 4 x \\
\text { percobaan } \\
\text { - pengenalan objek selama } 5 \\
\text { detik }\end{array}$ \\
\hline 5 & & 30 Derajat & $40 \mathrm{CM}$ & $\begin{array}{l}\text { - marker terdeteksi pada } 4 x \\
\text { percobaan } \\
\text { - pengenalan objek selama } 5 \\
\text { detik }\end{array}$ \\
\hline 6 & & 15 Derajat & $30 \mathrm{CM}$ & $\begin{array}{l}\text { - marker tidak dapat } \\
\text { terdeteksi }\end{array}$ \\
\hline 7 & & 0 Derajat & $20 \mathrm{CM}$ & $\begin{array}{l}\text { - marker tidak dapat } \\
\text { terdeteksi }\end{array}$ \\
\hline 8 & \multirow{3}{*}{$\begin{array}{c}150 \text { Lux } \\
\text { (kondisi siang hari } \\
\text { dengan } \\
\text { pencahayaan } \\
\text { dalam ruangan) }\end{array}$} & 90 Derajat & $80 \mathrm{CM}$ & $\begin{array}{l}\text { - marker terdeteksi pada } 1 x \\
\text { percobaan } \\
\text { - pengenalan objek selama } 2 \\
\text { detik }\end{array}$ \\
\hline 9 & & 75 Derajat & $70 \mathrm{CM}$ & $\begin{array}{l}\text { - marker terdeteksi pada } 1 \mathrm{x} \\
\text { percobaan } \\
\text { - pengenalan objek selama } 2 \\
\text { detik }\end{array}$ \\
\hline 10 & & 60 Derajat & $60 \mathrm{CM}$ & $\begin{array}{l}\text { - marker terdeteksi pada } 1 \mathrm{x} \\
\text { percobaan }\end{array}$ \\
\hline
\end{tabular}


45 Derajat

$50 \mathrm{CM}$ percobaan

\begin{tabular}{|c|c|c|c|c|}
\hline & & & & detik \\
\hline 12 & & 30 Derajat & $40 \mathrm{CM}$ & $\begin{array}{l}\text { - marker terdeteksi pada } 1 x \\
\text { percobaan } \\
\text { - pengenalan objek selama } 2 \\
\text { detik }\end{array}$ \\
\hline 13 & & 15 Derajat & $30 \mathrm{CM}$ & $\begin{array}{l}\text { - marker terdeteksi pada } 3 x \\
\text { percobaan } \\
\text { - pengenalan objek selama } 3 \\
\text { detik }\end{array}$ \\
\hline 14 & & 0 Derajat & $20 \mathrm{CM}$ & $\begin{array}{l}\text { - marker tidak dapat } \\
\text { terdeteksi }\end{array}$ \\
\hline 15 & \multirow{7}{*}{$\begin{array}{c}346 \text { Lux } \\
\text { (kondisi siang hari } \\
\text { dengan } \\
\text { pencahayaan } \\
\text { sinar matahari } \\
\text { luar ruangan) }\end{array}$} & 90 Derajat & $80 \mathrm{CM}$ & $\begin{array}{l}\text { - marker terdeteksi pada } 1 x \\
\text { percobaan } \\
\text { - pengenalan objek selama } 1 \\
\text { detik }\end{array}$ \\
\hline 16 & & 75 Derajat & $70 \mathrm{CM}$ & $\begin{array}{l}\text { - marker terdeteksi pada } 1 x \\
\text { percobaan } \\
\text { - pengenalan objek selama } 1 \\
\text { detik }\end{array}$ \\
\hline 17 & & 60 Derajat & $60 \mathrm{CM}$ & $\begin{array}{l}\text { - marker terdeteksi pada } 1 x \\
\text { percobaan } \\
\text { - pengenalan objek selama } 1 \\
\text { detik }\end{array}$ \\
\hline 18 & & 45 Derajat & $50 \mathrm{CM}$ & $\begin{array}{l}\text { - marker terdeteksi pada } 1 \mathrm{x} \\
\text { percobaan } \\
\text { - pengenalan objek selama } 1 \\
\text { detik }\end{array}$ \\
\hline 19 & & 30 Derajat & $40 \mathrm{CM}$ & $\begin{array}{l}\text { - marker terdeteksi pada } 1 x \\
\text { percobaan } \\
\text { - pengenalan objek selama } 1 \\
\text { detik }\end{array}$ \\
\hline 20 & & 15 Derajat & $30 \mathrm{CM}$ & $\begin{array}{l}\text { - marker terdeteksi pada } 2 x \\
\text { percobaan } \\
\text { - pengenalan objek selama } 2 \\
\text { detik }\end{array}$ \\
\hline 21 & & 0 Derajat & $20 \mathrm{CM}$ & $\begin{array}{l}\text { - marker tidak dapat } \\
\text { terdeteksi }\end{array}$ \\
\hline
\end{tabular}

Tabel 4. Tabel Pengujian Baca Marker Perangkat Xiaomi Redmi Note 5

\begin{tabular}{ccccc}
\hline No & $\begin{array}{c}\text { Kondisi Cahaya } \\
\text { (Lux) }\end{array}$ & $\begin{array}{c}\text { Sudut Baca } \\
\text { Marker }\end{array}$ & $\begin{array}{c}\text { Jarak Baca } \\
\text { Marker }\end{array}$ & Keterangan \\
\hline 1 & 2 Lux & 90 Derajat & $80 \mathrm{CM}$ & - percobaan dilakukan 2x \\
\hline
\end{tabular}




\begin{tabular}{|c|c|c|c|c|}
\hline & \multirow{7}{*}{$\begin{array}{l}\text { (kondisi malam } \\
\text { hari dengan } \\
\text { pencahayaan } \\
\text { ruangan) }\end{array}$} & & & $\begin{array}{l}\text { - pengenalan objek selama } 2 \\
\text { detik }\end{array}$ \\
\hline 2 & & 75 Derajat & $70 \mathrm{CM}$ & $\begin{array}{l}\text { - marker terdeteksi pada } 2 x \\
\text { percobaan } \\
\text { - pengenalan objek selama } 2 \\
\text { detik }\end{array}$ \\
\hline 3 & & 60 Derajat & $60 \mathrm{CM}$ & $\begin{array}{l}\text { - marker terdeteksi pada } 2 x \\
\text { percobaan } \\
\text { - pengenalan objek selama } 2 \\
\text { detik }\end{array}$ \\
\hline 4 & & 45 Derajat & $50 \mathrm{CM}$ & $\begin{array}{l}\text { - marker terdeteksi pada } 2 x \\
\text { percobaan } \\
\text { - pengenalan objek selama } 4 \\
\text { detik }\end{array}$ \\
\hline 5 & & 30 Derajat & $40 \mathrm{CM}$ & $\begin{array}{l}\text { - marker terdeteksi pada } 2 x \\
\text { percobaan } \\
\text { - pengenalan objek selama } 4 \\
\text { detik }\end{array}$ \\
\hline 6 & & 15 Derajat & $30 \mathrm{CM}$ & $\begin{array}{l}\text { - marker terdeteksi pada } 2 x \\
\text { percobaan } \\
\text { - pengenalan objek selama } 4 \\
\text { detik }\end{array}$ \\
\hline 7 & & 0 Derajat & $20 \mathrm{CM}$ & $\begin{array}{l}\text { - marker tidak dapat } \\
\text { terdeteksi }\end{array}$ \\
\hline 8 & & 90 Derajat & $80 \mathrm{CM}$ & $\begin{array}{l}\text { - marker terdeteksi pada } 1 x \\
\text { percobaan } \\
\text { - pengenalan objek selama } 1 \\
\text { detik }\end{array}$ \\
\hline 9 & & 75 Derajat & $70 \mathrm{CM}$ & $\begin{array}{l}\text { - marker terdeteksi pada 1x } \\
\text { percobaan } \\
\text { - pengenalan objek selama } 1 \\
\text { detik }\end{array}$ \\
\hline 10 & $\begin{array}{l}150 \text { Lux } \\
\text { (kondisi siang hari }\end{array}$ & 60 Derajat & $60 \mathrm{CM}$ & $\begin{array}{l}\text { - marker terdeteksi pada 1x } \\
\text { percobaan } \\
\text { - pengenalan objek selama } 1 \\
\text { detik }\end{array}$ \\
\hline 11 & $\begin{array}{c}\text { dengan } \\
\text { pencahayaan } \\
\text { dalam ruangan) }\end{array}$ & 45 Derajat & $50 \mathrm{CM}$ & $\begin{array}{l}\text { - marker terdeteksi pada 1x } \\
\text { percobaan } \\
\text { - pengenalan objek selama } 2 \\
\text { detik }\end{array}$ \\
\hline 12 & & 30 Derajat & $40 \mathrm{CM}$ & $\begin{array}{l}\text { - marker terdeteksi pada } 1 \mathrm{x} \\
\text { percobaan } \\
\text { - pengenalan objek selama } 1 \\
\text { detik }\end{array}$ \\
\hline 13 & & 15 Derajat & $30 \mathrm{CM}$ & $\begin{array}{l}\text { - marker terdeteksi pada } 1 \mathrm{x} \\
\text { percobaan } \\
\text { - pengenalan objek selama } 1 \\
\text { detik }\end{array}$ \\
\hline
\end{tabular}




\begin{tabular}{|c|c|c|c|c|}
\hline 14 & & 0 Derajat & $80 \mathrm{CM}$ & $\begin{array}{l}\text { percobaan } \\
\text { - pengenalan objek selama } 4 \\
\text { detik }\end{array}$ \\
\hline 15 & \multirow{7}{*}{$\begin{array}{c}346 \text { Lux } \\
\text { (kondisi siang hari } \\
\text { dengan } \\
\text { pencahayaan } \\
\text { sinar matahari } \\
\text { luar ruangan) }\end{array}$} & 90 Derajat & $70 \mathrm{CM}$ & $\begin{array}{l}\text { - marker terdeteksi pada 1x } \\
\text { percobaan } \\
\text { - pengenalan objek selama } 1 \\
\text { detik }\end{array}$ \\
\hline 16 & & 75 Derajat & $60 \mathrm{CM}$ & $\begin{array}{l}\text { - marker terdeteksi pada 1x } \\
\text { percobaan } \\
\text { - pengenalan objek selama } 1 \\
\text { detik }\end{array}$ \\
\hline 17 & & 60 Derajat & $50 \mathrm{CM}$ & $\begin{array}{l}\text { - marker terdeteksi pada 1x } \\
\text { percobaan } \\
\text { - pengenalan objek selama } 1 \\
\text { detik }\end{array}$ \\
\hline 18 & & 45 Derajat & $40 \mathrm{CM}$ & $\begin{array}{l}\text { - marker terdeteksi pada } 1 \mathrm{x} \\
\text { percobaan } \\
\text { - pengenalan objek selama } 1 \\
\text { detik }\end{array}$ \\
\hline 19 & & 30 Derajat & $30 \mathrm{CM}$ & $\begin{array}{l}\text { - marker terdeteksi pada } 1 x \\
\text { percobaan } \\
\text { - pengenalan objek selama } 1 \\
\text { detik }\end{array}$ \\
\hline 20 & & 15 Derajat & $20 \mathrm{CM}$ & $\begin{array}{l}\text { - marker terdeteksi pada 1x } \\
\text { percobaan } \\
\text { - pengenalan objek selama } 1 \\
\text { detik }\end{array}$ \\
\hline 21 & & 0 Derajat & $80 \mathrm{CM}$ & $\begin{array}{l}\text { - marker terdeteksi pada 1x } \\
\text { percobaan } \\
\text { - pengenalan objek selama } 2 \\
\text { detik }\end{array}$ \\
\hline
\end{tabular}

Tabel 5. Pengujian Menu Virtual Reality pada aplikasi

\begin{tabular}{|c|c|c|c|}
\hline No & Tipe Perangkat & $\begin{array}{l}\text { Tes Kemampuan } \\
\text { Rendering }\end{array}$ & Keterangan \\
\hline \multirow{3}{*}{1} & \multirow{3}{*}{ Xiaomi Redmi Note 2} & Eksplorasi Kedepan & Kemampuan Rendering Lancar \\
\hline & & Eksplorasi Kekiri & $\begin{array}{l}\text { Kemampuan Rendering Sedikit Patah- } \\
\text { Patah }\end{array}$ \\
\hline & & Eksplorasi Kekanan & $\begin{array}{l}\text { Kemampuan Rendering Sedikit Patah- } \\
\text { Patah }\end{array}$ \\
\hline \multirow{3}{*}{2} & \multirow{3}{*}{ Galaxy A5 2017} & Eksplorasi Kedepan & Kemampuan Rendering Lancar \\
\hline & & Eksplorasi Kekiri & $\begin{array}{l}\text { Kemampuan Rendering Sedikit Patah- } \\
\text { Patah }\end{array}$ \\
\hline & & Eksplorasi Kekanan & Kemampuan Rendering Sedikit Lancar \\
\hline \multirow{3}{*}{3} & \multirow{3}{*}{ Xiaomi Redmi Note 5} & Eksplorasi Kedepan & Kemampuan Rendering Sangat Lancar \\
\hline & & Eksplorasi Kekiri & Kemampuan Rendering Lancar \\
\hline & & Eksplorasi Kekanan & Kemampuan Rendering Lancar \\
\hline
\end{tabular}


Dalam pengujian oleh pengguna, hasil pengujian pada aplikasi dilakukan melalui kuisioner yang dibuat menggunakan aplikasi Google Form dan dilakukan testing secara langsung oleh pengguna. Terdapat 3 aspek penilaian, diantaranya Aspek Desain, Aspek Informasi, Aspek Navigasi. Aspek Desain meliputi : Model 3D, Animasi, Tata Letak/Layout. Aspek Informasi meliputi : Konten yang mudah dipahami, keterbacaan teks informasi, dan kualitas dari audio/suara. Aspek Navigasi meliputi : Kemudahan dalam penggunaan aplikasi AR, Kemudahan dalam penggunaan aplikasi VR, Kemudahan dalam menjelajah aplikasi AR, serta Kemudahan dalam menjelah aplikasi VR. Aspek Desain mendapatkan 29,7\% Sangat Baik dan 70,3\% Sangat Baik Sekali. Aspek Informasi mendapatkan 40,8\% Sangat Baik dan 59,2\% Sangat Baik Sekali. Dan Aspek Navigasi mendapatkan 19,4\% Sangat Baik dan $80,5 \%$ Sangat Baik Sekali.

Tabel 6. Grafik Kuisioner.

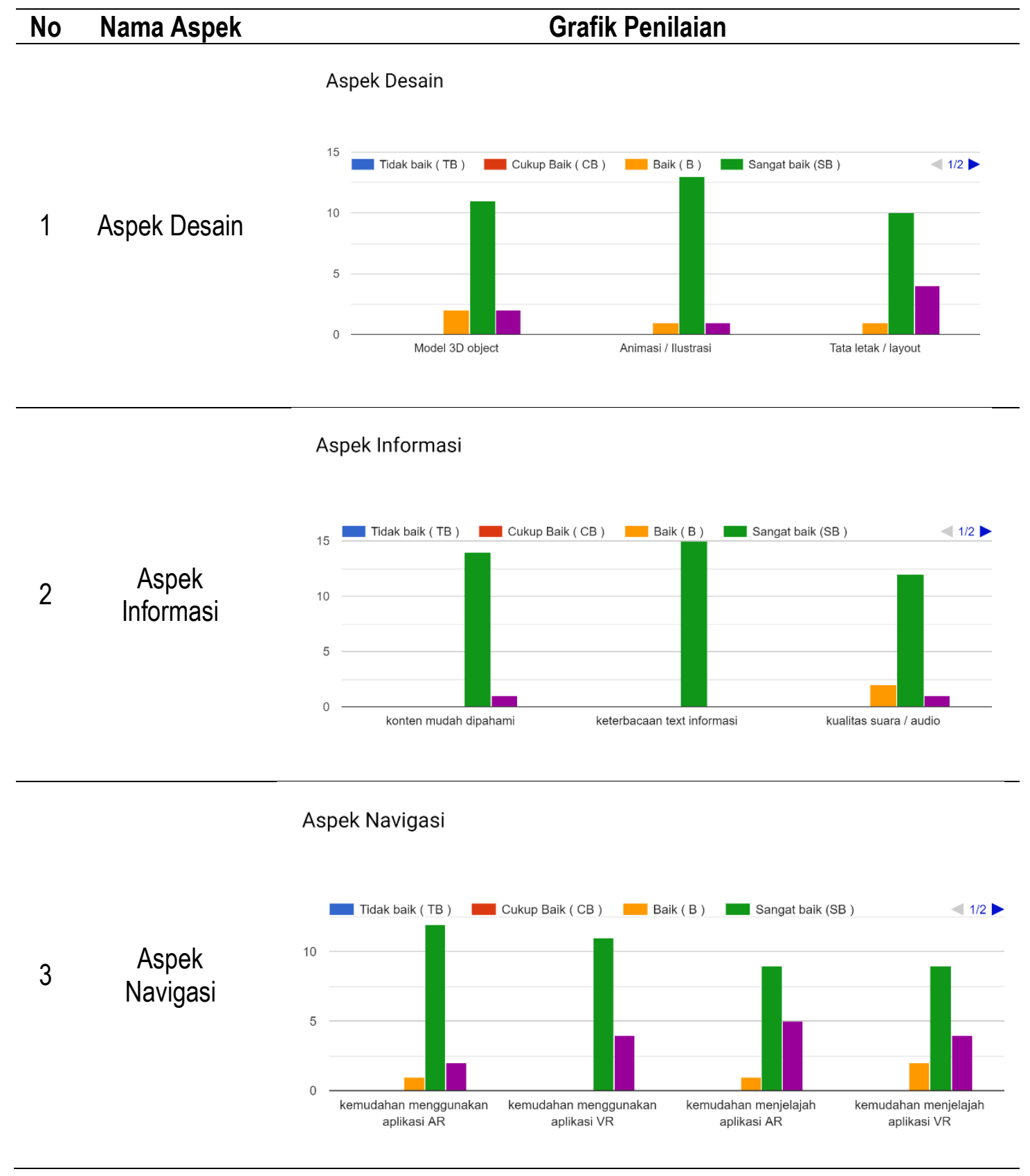


Berdasarkan penelitian yang dilakukan yaitu telah berhasil dilakukan Pembuatan AR dan VR Model Planet Tata Surya Galaksi Bima Sakti Sebagai Media Pembelajaran Siswa Sekolah Menengah Pertama (SMP) yang berbasis Android. Efektivitas aplikasi dalam memberikan informasi mendapat nilai 100\% dapat diterima oleh responden. Konten pada aplikasi AR dan VR Model Planet Tata Surya Galaksi Bima Sakti Sebagai Media Pembelajaran Siswa Sekolah Menengah Pertama (SMP) adalah berupa pembahasan tentang materi Tata Surya yang diajarkan di Sekolah Menengah Pertama. Aplikasi ini merupakan file dengan ekstensi .apk berukuran $167 \mathrm{MB}$. Aplikasi AR dan VR ini dijalankan secara optimal dengan spesifikasi perangkat Quadcore $1.5 \mathrm{Ghz}$ serta memiliki RAM $3 \mathrm{~GB}$ dan memiliki sensor gyro. Adapun hasil kuisioner yang diberikan kepada 9 responden yang merupakan Siswa SMP yaitu Aspek Desain mendapatkan jumlah nilai Sangat Baik dan Sangat Baik Sekali sebesar 100\% . Aspek Informasi mendapatkan nilai Sangat Baik dan Sangat Baik Sekali sebesar 100\%. Dan Aspek Navigasi mendapatkan jumlah nilai Sangat Baik dan Sangat Baik Sekali sebesar 99.9\%..

\section{DAFTAR PUSTAKA}

Ahmad, W., Wan, J., \& Ahmad, A. (2017). The effectiveness of signaling principle in virtual reality courseware towards achievement of transfer learning among students with different spatial ability The Effectiveness of Signaling Principle in Virtual Reality Courseware towards Achievement of Tra (Vol. 020144, pp. 1-6). AIP Publishing.

Ajanki, A., Billinghurst, M., Gamper, H., Ja, T., Kandemir, M., Kaski, S., ... Puolama, K. (2011). An augmented reality interface to contextual information, 161-173. https://doi.org/10.1007/s10055010-0183-5

Azuma, R., \& Azuma, R. (1997). A survey of augmented reality. Presence: Teleoperators and Virtual Environments, 6(4), 355-385. https://doi.org/10.1.1.30.4999

Chang, K. E., Chang, C. T., Hou, H. T., Sung, Y. T., Chao, H. L., \& Lee, C. M. (2014). Development and behavioral pattern analysis of a mobile guide system with augmented reality for painting appreciation instruction in an art museum. Computers and Education, 71, 185-197. https://doi.org/10.1016/j.compedu.2013.09.022

Feng, Z., González, V. A., Amor, R., Lovreglio, R., \& Cabrera-guerrero, G. (2018). Computers \& Education Immersive virtual reality serious games for evacuation training and research: A systematic literature review. Computers \& Education, 127(September), 252-266. https://doi.org/10.1016/j.compedu.2018.09.002

Fleck, S., Simon, G., \& Bastien, J. M. C. (2014). [ Poster ] AIBLE : An Inquiry-Based Augmented Reality Environment for Teaching Astronomical Phenomena. In 2014 IEEE International Symposium on Mixed and Augmented Reality - Media, Art, Social Science, Humanities and Design (ISMARMASH'D) (pp. 65-66). Munich, Germany: IEEE. https://doi.org/10.1109/ISMARAMH.2014.6935440

Gelisli, Y., \& Yazici, E. (2015). A Study into Traditional Child Games Played in Konya Region in Terms of Development Fields of Children. Procedia - Social and Behavioral Sciences, 197(February), 18591865. https://doi.org/10.1016/j.sbspro.2015.07.247

Geroimenko, V. (2012). Augmented Reality Technology and Art: The Analysis and Visualization of Evolving Conceptual Models. IEEE, 445-453. https://doi.org/10.1109/IV.2012.77

K.Wahyudi, A. (2014). Arca: Pengembangan Buku Interaktif Berbasis Augmented Reality pada Pengenalan dan Pembelajaran Candi Prambanan dengan Smartphone Berbasis Android, 3(2), 96102. 
Lin, L., Wang, Y., \& Liu, Y. (2008). Marker-less registration based on template tracking for augmented reality. https://doi.org/10.1007/s11042-008-0227-y

Mallem, M. (2010). Augmented Reality : Issues , Trends and Challenges, (October 2008), 7248.

Nassar, M. A., \& Meawad, F. (2010). An augmented reality exhibition guide for the iphone. Proceedings - 2010 International Conference on User Science and Engineering, i-USEr 2010, 157-162. https://doi.org/10.1109/IUSER.2010.5716742

Prayudha, I. P. A., Agung, A. A. K., Wiranatha, C., \& Raharja, I. M. S. (2017). Aplikasi Virtual Reality Media Pembelajaran Sistem Tata Surya. MERPATI, 5(2), 72-80.

Purnomo, F. A., Santosa, P. I., Hartanto, R., Pratisto, E. H., \& Purbayu, A. (2018). Implementation of Augmented Reality Technology in Sangiran Museum with Vuforia. In IOP Conference Series: Materials Science and Engineering (Vol. 333). https://doi.org/10.1088/1757-899X/333/1/012103

Purnomo, F. A., Santoso, I., \& Hartanto, R. (2017). 2017. In International Conference on Advanced Materials for Better Future (pp. 1-6). https://doi.org/10.1088/1757-899X/333/1/012103

Silva, R., Oliveira, J. C., \& Giraldi, G. A. (n.d.). Introduction to Augmented Reality.

Sugianto, C. A. (2015). APLIKASI EDUKASI TATA SURYA MENGGUNAKAN. Bandung. https://doi.org/DOI 10.17605/OSF.IO/JGDPX

Tussyadiah, I. P., Wang, D., Jung, T. H., \& Claudia, M. (2018). Virtual reality , presence, and attitude change: Empirical evidence from tourism. Tourism Management, 66, 140-154. https://doi.org/10.1016/j.tourman.2017.12.003

Wang, C. (2012). 3D Augmented Reality Mobile Navigation System Supporting Indoor Positioning Function, 64-68.

Wang, Z. B., Shen, Y., Ong, S. K., \& Nee, A. Y. C. (2009). Assembly design and evaluation based on bare-hand interaction in an augmented reality environment. 2009 International Conference on CyberWorlds, CW '09, 21-28. https://doi.org/10.1109/CW.2009.15

How to cite: Purnomo, F.A., Ayunigrat, S. J., Lukitasari, Y., Kusuma, A. N. (2020). Evaluasi media pembelajaran interaktif pengenalan tata surya dengan teknologi augmented reality dan virtual reality. Teknodika, 18 (1), 1-15. DOI: https://doi.org/10.20961/teknodika.v18i1.34963 